\title{
Incidental Prostate Adenocarcinoma in Prostate Transurethral Resections: Our Eight Year Experience
}

\section{Prostat Transüretral Rezeksiyonlarında Rastlantısal Prostat Adenokarsinomu: Sekiz Yıllık Deneyimimiz}

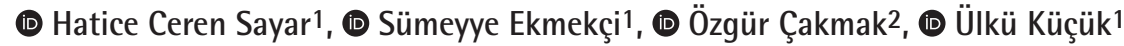 \\ 1 İzmir Tepecik Training and Research Hospital, Clinic of Pathology, İzmir, Turkiye \\ 2 Izmir Tepecik Training and Research Hospital, Clinic of Urology, Izmir, Turkiye
}

What's known on the subject? and What does the study add?

Incidental early-stage prostate cancer (PC) can be detected in patients undergoing transurethral resection of the prostate (TURP) for the treatment of lower urinary tract symptoms due to benign prostatic hyperplasia (BPH). This article is an original study focusing on detecting the incidental prostate cancer in patients undergoing transurethral prostate resection for benign prostate hyperplasia. We investigated the incidence of incidental PC and the relationship between age, resected prostate tissue volume and serum PSA levels in patients undergoing TURP for BPH in our hospital.

\begin{abstract}
Objective: Incidental early-stage prostate cancer (PC) can be detected in patients undergoing transurethral resection of the prostate (TURP) due to benign prostatic hyperplasia (BPH). In our study, we investigated the incidence of incidental PC and the relationship of the incidence of PC with age, serum prostate specific antigen (PSA) levels and resected prostate tissue volume in patients undergoing TURP for BPH.

Materials and Methods: A total of 391 patients, who underwent TURP for BPH in our hospital between 2011 and 2018, were included in the study. Age and volumes of resection materials of the cases were obtained from pathology reports and blood PSA levels were obtained from the urology clinic.

Results: In our series, incidental PC was detected in 17 of 391 cases (4.3\%). The mean age of the patients with and without tumor was 74.5 years 69.5 years, respectively. The mean preoperative PSA level was $5.05 \mathrm{ng} / \mathrm{mL}$ in 226 patients without PC and the mean preoperative PSA level was 4.46 $\mathrm{ng} / \mathrm{mL}$ in 15 patients with PC whose preoperative PSA levels could be checked by the urology clinic.

Conclusion: In our study, incidental PC detection rate $(<5 \%)$ in surgical specimens of patients undergoing TURP for BPH was found to be compatible with the literature. The incidence of PC was found to be higher, especially in patients aged 70 years and older. In these patients, preoperative serum PSA levels were lower than those without tumor. histopathological examination of all TURP materials, especially those obtained in patients of advanced age undergoing TURP with, a preliminary diagnosis of $\mathrm{BPH}$, are important in terms of avoiding underdiagnosis.
\end{abstract}

Keywords: Incidental, Prostate carcinoma, Transurethral Resection of the Prostate

Öz

Amaç: Rastlantısal erken evre prostat kanseri (PK), benign prostat hiperplazisi (BPH) nedeniyle transüretral prostat rezeksiyonu (TURP) yapılan hastalarda tespit edilebilir. Çalışmamızda hastanemizde BPH nedeniyle TURP uygulanan hastalarda rastlantısal PK insidansı ve yaş, rezeke prostat dokusu hacmi ve serum prostat spesifik antijen (PSA) düzeyleri arasındaki ilişkiyi araştırdık.

Gereç ve Yöntem: Çalışmamıza 2011 ve 2018 yılları arasında hastanemizde BPH nedeniyle TURP uygulanan 391 hasta dahil edildi. Olguların yaş ve TURP hacimleri patoloji raporlarından, serum PSA düzeyleri üroloji kliniğinden elde edildi.

Bulgular: Serimizdeki 391 olgunun 17'sinde $(\% 4,3)$ rastlantısal PK tespit edildi. Tümörü olan hastaların yaş ortalaması 74,5, tümörü olmayanların yaş ortalaması 69,5 idi. Preoperatif PSA düzeyleri 226 hastada ortalama $5.05 \mathrm{ng} / \mathrm{mL}$ iken, PK'li 15 hastada ortalama PSA düzeyi $4.46 \mathrm{ng} / \mathrm{mL}$ idi.

Sonuç: Çalışmamızda BPH için TURP materyallerinde rastlantısal PK saptama oranı (<\%5) literatürle paralel bulundu. Rastlantısal PK insidansı,

Correspondence: Hatice Ceren Sayar MD, İmir Tepecik Training and Research Hospital, Clinic of Pathology, İmir, Turkiye E-mail: cerensayar@gmail.com ORCID-ID: orcid.org/0000-0002-9590-4699

Received: 19.12.2019 Accepted: 07.01.2020

Cite this article as: Sayar HC, Ekmekçi S, Çakmak Ö, Küçük Ü. Incidental Prostate Adenocarcinoma in Prostate Transurethral Resections: Our Eight Year Experience. J Urol Surg 2020;7(2):88-91.

๑Copyright 2020 by the Association of Urological Surgery / Journal of Urological Surgery published by Galenos Publishing House. 
özellikle 70 yaş ve üstü olgularda daha yüksek bulunmuştur. Bu hastalarda preoperatif serum PSA düzeyleri tümörsüzlere göre düşüktü. Bu, tüm TURP materyalinin, histopatolojik incelenmesi, özellikle de BPH ön tanısıyla yapılan ileri yaştakilerin, tümörü atlamama açısından önemli olduğunu göstermektedir.

Anahtar Kelimeler: Rastlantısal, Prostat karsinomu, Transüretral Prostat Rezeksiyonu

\section{Introduction}

Transurethral resection of the prostate (TURP) is a frequently used surgical method for the treatment of benign prostatic hyperplasia (BPH) (1). Incidental early-stage prostate cancer (PC) can be diagnosed by clinical examination and/or imaging methods in patients undergoing TURP for BPH (2). By the introduction of serum prostate specific antigen (PSA) testing, the incidence of of PC decreased from $27 \%$ to $5-13 \%$ in the last twenty years (2).

In our study, we investigated the incidence of PC in patients who underwent TURP for BPH in our hospital and its relationship with age, resected prostate tissue volume and PSA level.

\section{Materials and Methods}

Patients, who underwent TURP for BPH in our hospital between January 2011 and December 2018, were included in the study. Data on age and preoperative serum PSA levels were obtained from the urology clinic, TURP material volume and histopathological examination results were obtained from the pathology reports. Ethics committee approval is registered with the decision number 2019/11-20 on 11.07.2019.

\section{Results}

A total of 391 patients underwent TURP due to BPH between January 2011 and December 2018. 17 (4.3\%) were diagnosed with PC after histopathological examination. The mean age of 374 patients with no tumor was $69.5 \pm 9.01$ (26-93) years and the mean age of 17 patients with tumor was 74.5 (54-93). Two patients were in the age group of 50-60 years, 2 in the 61-70 years, 8 in the 71-80 years, 5 were older than 80 years of age.

The mean preoperative PSA level in 226 patients without tumor and 17 patients with tumor, whose preoperative PSA levels could be checked by the urology clinic, was $5.05 \pm 7.01 \mathrm{ng} / \mathrm{mL}$ (0.1- $69.3 \mathrm{ng} / \mathrm{mL}$ and $4.46 \pm 7.27 \mathrm{ng} / \mathrm{mL}(0.40-28.5)$, respectively.

The mean volume of TURP material in patients with and without tumor was $12.7 \pm 13.01(0.3-150)$ cc and $12 \pm 9.15$ (1.5-40) cc, respectively. Of the 17 patients with tumor, 5 had a TURP volume of $<10 \mathrm{cc}, 12 \mathrm{had} \geq 10 \mathrm{cc}$ (Table 1 ).

Twelve of the detected tumors were Grade Group 1 (GG 1), 3 were $\mathrm{GG}$ 2, one was $\mathrm{GG} 3$ and 1 was $\mathrm{GG} 4$. In 11 cases, involved less than 5\% (T1a) and six involved more than 5\% (T1b) of the material (Table 2).

\section{Discussion}

PC is the second most common type of cancer in men and is one of the leading causes of death in developed countries $(2,3,4)$. $\mathrm{BPH}$ and carcinoma of the prostate are more frequent after the age of 50 and the prevalence of PC doubles every 14 years $(5,6)$. Clinically, T1 or incidental PC is known to be a tumor that can not be detected by clinical examination and imaging methods (2).

The incidence of incidentally detected $\mathrm{PC}$ in patients undergoing TURP due to BPH has been reported to be less than 5\% (7). Vargheseve et al. (2) reported that the incidence of incidental PC was 5.2\% in a series of 597 patients who underwent TURP and that the maximum incidence of occult PC was in the 70-79 age group (18/31 cases).

Otto et al. (8) reported that incidental PC was detected in 11 cases $(1.4 \%)$ in the series of 771 patients who underwent

Table 1. Distribution of diagnostic groups of cases according to numbers of patients, mean age, the mean level of prostate specific antigen and mean transurethral prostate resection volume

\begin{tabular}{|l|l|l|}
\hline & Benign (\%) & Malignant (\%) \\
\hline Number of patients & $374(95.7)$ & $17(4.3)$ \\
\hline Mean age & $69.5(26-93)$ & $74.5(54-93)$ \\
\hline $\begin{array}{l}\text { The mean PSA level } \mathbf{( n g} / \\
\mathbf{m L})\end{array}$ & $5.05(0.5-69.3)$ & $4.46(0.4-28.5)$ \\
\hline Mean TURP volume & $12.7 \mathrm{cc}$ & $<10$ cc (5 patients) \\
\cline { 2 - 3 } & & $\geq 10$ cc (12 patients) \\
\hline PSA Prosta specific antigen, & &
\end{tabular}

PSA: Prostate specific antigen, TURP: Transurethral resection of the prostate

Table 2. Distribution of prostate cancer patients according to age of patients (left). Distribution of prostate cancer patients according to grade groups (right)

\begin{tabular}{|l|l|l|l|}
\hline PC patients & Number $(\mathrm{N})$ & PC patients & Number $(\mathrm{N})$ \\
\hline Age range (year) & & Grade group (GG) & \\
\hline $50-60$ & 2 & $\mathrm{GG} 1$ & 12 \\
\hline $61-70$ & 2 & $\mathrm{GG} 2$ & 3 \\
\hline $71-80$ & 8 & $\mathrm{GG} 3$ & 1 \\
\hline$>80$ & 5 & $\mathrm{GG} 4$ & 1 \\
\hline & $\mathrm{GG5}$ & 0 \\
\hline PC: Prostate cancer & &
\end{tabular}


TURP and that the age of the patients with tumor ranged from 59 to 85 years. In their study including 145 patients with incidental PC Lee et al. (7) reported that the average age of the patients was 69.5 years. In a single-center study, Capogrosso et al. (9) evaluated 1177 patients who underwent surgery (open prostatectomy, transurethral resection, or holmium laser enucleation of the prostate) for BPH between 2007 and 2016. Incidental PC was found in 6.4\% (74) of the patients. In our series, incidental PC was detected in 17 (4.3\%) of 391 patients and the mean age was 75.2 years in patients with tumor and 13 of 17 cases $(76 \%)$ were over 71 years of age. The mean age of the patients was higher than in the study by Capogrosso et al. (9).

In one study from Turkey including 120 patients who underwent TURP, the incidence of incidental prostate carcinoma patients was found to be $2.5 \%$. The other diagnoses established through TURP were chronic non-specific hyperplasia and BPH (46.7\%), active chronic prostatitis $(25.6 \%), \mathrm{BPH}(13.3 \%)$, atypical foci suspicious for malignancy $(6.6 \%)$, and granulomatous prostatitis $(1.7 \%)(10)$.

PSA is a specific protein released from the prostate tissue but is not a specific marker for cancer. Nowadays, it is accepted that serum PSA is strongly associated with PC and is an important marker that can be used in diagnosis and followup after treatment (11). However, serum PSA levels increase in $\mathrm{BPH}$, prostatitis and mechanical manipulation as well as PC $(2,11,12,13)$. With the advent of PSA testing in routine followup, the incidence of incidental PC decreased compared to the pre-PSA period $(2,7,14)$. In our series, PSA levels were higher than normal in both groups, and the mean serum PSA level was found to be higher in patients with no tumor.

Lee et al. (7) reported that the average serum PSA level in 156 patients with incidental PC before and after TURP was $4.57 \mathrm{ng} /$ $\mathrm{mL}$ and $1.43 \pm 1.66 \mathrm{ng} / \mathrm{mL}$, respectively. $62.2 \%$ of patients had T1a, 37.8\% had T1b. In the study by Capogrosso et al. (9), 67 (91\%) of 74 patients with incidental PC were found to have GG1 disease and $86 \%$ of PC were stage T1a. Similarly, in our series, $62.5 \%$ of the cases were staged $\mathrm{T} 1 \mathrm{a}, 37.5 \%, \mathrm{~T} 1 \mathrm{~b}$, and 11 (64.7\%) of 17 tumors were classified as GG1.

Leite et al. reported that the mean PSA level in 1081 who underwent prostate biopsy was $7.43 \mathrm{ng} / \mathrm{mL}$. 376 of them had PC and the mean PSA level was higher than $4 \mathrm{ng} / \mathrm{mL}$ in 288 (35.7\%) of PC cases (15). In our study, the mean serum PSA level in 226 patients (that could be checked by the urology clinic) was 5.05 $\mathrm{ng} / \mathrm{mL}$. The mean PSA level in 17 patients with PC was higher than $4 \mathrm{ng} / \mathrm{mL}$.

Bollito et al. (16) found no association between the stage of PC and $\mathrm{PC}$ volume at the time of diagnosis, and attributed this to increased use of PSA testing. In our series, preoperative serum PSA levels may also be elevated for non-tumor reasons and may even be higher than those detected.

TURP remains the most commonly used surgical approach in the treatment of BPH (1). The College of American Pathologists (CAP) recommends that all materials of $12 \mathrm{~g}$ or less be processed in 6-8 cassettes, with an additional cassette for each $5 \mathrm{~g}$ after the first $12 \mathrm{~g}$ of materials weighing more than $12 \mathrm{~g}$ (17). When incidental PC is detected in a TURP sample, it is controversial how much additional material is required to accurately estimate tumor volume and to find the Gleason score of these tumors detected in the resected material (2). The CAP recommends that if the PC focus is detected to be $5 \%$ or less of the received materials in the histopathological examination, all the remaining tissue should be processed and examined (17).

In our pathology department, our general approach is to process all of the submitted TURP materials, but if all of the material was not taken and incidental PC was detected in the sections, we process all the remaining tissue to determine the tumor percentage and Gleason score.

In the guideline prepared by the Turkish Federation of Pathology, it is recommended that the ratio of the tumor detected in TURP material-to-normal prostate tissue is expressed as percentage (\%) (18). In our series, it was thought that the tumor volume was $<5 \%$ in most of the cases with tumors $>10$ cc with TURP material and the probability of missing the tumor would increase if all the material was not processed. In recent studies, however, there are also reports that classification according to the $5 \%$ threshold is not an independent prognostic factor in staging tumors $(9,19)$.

\section{Conclusion}

In our study, the incidence of incidental PC in TURP was found to be less than $5 \%$ and the incidence increased especially in patients aged $\geq 70$ years. It should be kept in mind that preoperative serum PSA levels may also be elevated for nontumor reasons and may even be higher than those detected in our series.

Even if the preliminary diagnosis of BPH is made, processing of all the TURP material, especially those obtained from elderly patients, and evaluating pre-operative PSA level are important not to miss any tumor.

\section{Ethics}

Ethics Committee Approval: Ethics committee approval is registered with the decision number 2019/11-20 on 11.07.2019. 
Informed Consent: Informed Consent: Consent form was filled out by all participants.

Peer-review: Externally and internally peer-reviewed.

\section{Authorship Contributions}

Concept: H.C.S., Design: H.C.S., Data Collection or Processing: H.C.S., S.E., Ö.Ç., Analysis or Interpretation: H.C.S., S.E., Ö.Ç., Literature Search: H.C.S., S.E., Ü.K., Writing: H.C.S.

Conflict of Interest: No conflict of interest was declared by the authors.

Financial Disclosure: The authors declare that they have no relevant financial disclosure.

\section{References}

1. Trpkov K, Thompson J, Kulaga A, Yilmaz A. How much tissue sampling is required when unsuspected minimal prostate carcinoma is identified on transurethral resection? Arch Pathol Lab Med 2008;132:1313-1316.

2. Varghese J, Kuruvilla PM, Mehta N, Rathore RS, Babu M, Bansal D, Pillai B, Sam MP, Krishnamorthy H. Incidentally Detected Adenocarcinoma Prostate in Transurethral Resection of Prostate Specimens: a Hospital Based Study from India. AsianPac J Cancer Prev 2016;17:2255-2258.

3. U.S. Cancer Statistics Working Group. United States Cancer Statistics: 19992011. Incidence and mortality web-based report. Atlanta, GA: Department of Health and Human Services, 2014.

4. OECD/European Union. Mortality from cancer. Health at a glance: Europe 2014. Paris: OECD Publishing, 2014.

5. Bozlu M. Prostat biyopsilerinin klinik yorumu. Üroonkoloji Bülteni 2007;2:811.

6. Bell KJ, Del Mar C, Wright G, Dickinson J, Glasziou P. Prevalence of incidental prostate cancer: A systematic review of autopsy studies. Int J Cancer 2015;137:1749-1757.

7. Lee DH, Chung DY, Lee KS, Kim IK, Rha KH, Choi YD, Chung BH, Hong SJ, Kim $\mathrm{JH}$. Clinical experiences of incidental prostate cancer after transurethral resection of prostate (TURP) according to initial treatment: a study of a Korean high volume center. Yonsei Med J 2014;55:78-83.

8. Otto B, Barbieri C, Lee $R$, Te AE, Kaplan SA, Robinson B, Chughtai B. Incidental prostate cancer in transurethral resection of the prostate specimens in the modern era. Adv Urol 2014;2014:627290.

9. Capogrosso P, Capitanio U, Vertosick EA, Ventimiglia E2, Chierigo F, Oreggia D, Moretti D, Briganti A, Vickers AJ, Montorsi F, Salonia A. Temporal Trend in Incidental Prostate Cancer Detection at Surgery for Benign Prostatic Hyperplasia. Urology 2018;122:152-157.

10. Fındık Güvendi G, Toyran T, Bağcıoğlu M, Kıııç Ö, Adalı Y. The Incidence and Significance of Incidental Prostate Carcinoma in Transurethral Resection (TUR-P) Materials between 2014 and 2016 at Our Center. Medical Sciences (NWSAMS), 2018;13:19-22.

11. WHO Classification of Tumours Editorial Board. World Health Organization (WHO) Classification of Tumors of the Urinary System and Male Genital Organs 2016, 4th ed.

12. Stamey TA, Yang N, Hay AR, McNeal JE, Freiha FS, Redwinw E. Prostatespecific antigen as a serum marker for adenocarcinoma of the prostate. $\mathrm{N}$ Engl J Med 1987;317:909.

13. Karabulut YY, Dölek Y, Özdemir Ü, Kurşun N. Documentation of Prostat Tur Materials in Cankırı Population: 133 Cases. Smyrna Tıp Dergisi.

14. Jones JS, Follis HW, Johnson JR. Probability of finding T1a and T1b (incidental) prostate cancer during TURP has decreased in the PSA era Prostate Cancer Prostatic Dis 2009;12:57-60.

15. Leite KR, Srougi M, Dall'Oglio MF, Sanudo A, Camara-Lopes LH. Histopathological findings in extended prostate biopsy with PSA $\leq 4 \mathrm{ng} / \mathrm{mL}$. Int Braz J Urol 2008;34:283-290; discussion 290-292.

16. Bollito E, Terrone C, Volpe A, Porpiglia F, Cracco C, Poggio M, Grande S, Righi L, Bellina M, Papotti M, Scarpa RM. Changes in prostate cancer at radical prostatectomy during the prostate specific antigen era: an Italian experience. Anal Quant Cytol Histol 2008 Jun;30:152-159.

17. Collage of American Pathologists (CAP). Protocol for the Examination of Specimens From Patients With Carcinoma of the Prostate Gland. 2017.

18. Patoloji Dernekleri Federasyonu, Üropatoloji Çalışma Grubu. Ürolojik Tümörlerin Patolojik Değerlendirme Standartları ve Kılavuzları. 2010.

19. Adolfsson J. The management of category T1a-T1b (incidental) prostate cancer: can we predict who needs treatment? Eur Urol 2008;54:16-18. 